OPEN ACCESS

Edited by:

Martin Johannes Hoogduijn,

Erasmus University Rotterdam,

Netherlands

Reviewed by:

Marcella Franquesa

IVECAT Group Institut d'Investigació

Germans Trias i Pujol, Spain

Verônica Coelho,

University of São Paulo, Brazil

${ }^{*}$ Correspondence:

Heidi Yeh

hyeh@mgh.harvard.edu

Specialty section:

This article was submitted to Alloimmunity and Transplantation,

a section of the journal

Frontiers in Immunology

Received: 03 October 2016

Accepted: 17 January 2017

Published: 02 February 2017

Citation:

Firl DJ, Benichou G, Kim Jl and Yeh $H$ (2017) A Paradigm Shift on the

Question of B Cells in

Transplantation? Recent Insights on

Regulating the Alloresponse.

Front. Immunol. 8:80.

doi: 10.3389/fimmu.2017.00080

\section{A Paradigm Shift on the Question of B Cells in Transplantation? Recent Insights on Regulating the Alloresponse}

\author{
Daniel J. Firl',2, Gilles Benichou', James I. Kim ${ }^{1}$ and Heidi Yeh ${ }^{1 *}$ \\ ${ }^{1}$ Transplant Center, Massachusetts General Hospital, Harvard Medical School, Boston, MA, USA, ${ }^{2}$ Howard Hughes \\ Medical Institute, Chevy Chase, MD, USA
}

B lymphocytes contribute to acute and chronic allograft rejection through their production of donor-specific antibodies (DSAs). In addition, B cells present allopeptides bound to self-MHC class II molecules and provide costimulation signals to $T$ cells, which are essential to their activation and differentiation into memory $T$ cells. On the other hand, both in laboratory rodents and patients, the concept of effector $T$ cell regulation by $\mathrm{B}$ cells is gaining traction in the field of transplantation. Specifically, clinical trials using anti-CD20 monoclonal antibodies to deplete B cells and reverse DSA had a deleterious effect on rates of acute cellular rejection; a peculiar finding that calls into question a central paradigm in transplantation. Additional work in humans has characterized IL-10-producing B cells (IgM memory and transitional B cells), which suppress the proliferation and inflammatory cytokine productions of effector $\mathrm{T}$ cells in vitro. Understanding the mechanisms of regulating the alloresponse is critical if we are to achieve operational tolerance across transplantation. This review will focus on recent evidence in murine and human transplantation with respect to non-traditional roles for B cells in determining clinical outcomes.

\footnotetext{
Keywords: regulatory B cells, transplant tolerance, antigen presentation, allorecognition, transplant rejection, autoimmune diseases
}

\section{INTRODUCTION}

Allorecognition refers to the detection by the immune system of polymorphic determinants expressed by different individuals of the same species (alloantigens) (1-3). After transplantation of allogeneic organs or tissues, recognition of alloantigens by host leukocytes initiates an inflammatory immune response leading to graft rejection $(4,5)$. It is now established that certain leukocytes of the innate immune system, including NK cells and macrophages, can distinguish between self- and non-self antigens and thereby contribute to the alloresponse (6-8). However, allorecognition by $\mathrm{T}$ lymphocytes of the adaptive immune system is the driving force behind alloimmunity and allograft rejection in vertebrates. After transplantation, graft $\mathrm{MHC}$ class $\mathrm{II}^{+}$cells as well as donor-derived extracellular vesicles traffic to the recipient lymphoid organs where they

\footnotetext{
Abbreviations: AMR, antibody-mediated rejection; APC, antigen-presenting cell; Breg, B regulatory cells; cGVHD, chronic graft versus host disease; CTL, cytotoxic T lymphocytes; DSAs, donor-specific antibodies; GC, germinal center; HSCT, hematopoietic stem cell transplant; TrB, transitional B cells.
} 
activate $\mathrm{CD}^{+}$allospecific $\mathrm{T}$ cells (9-12). This process occurs via two distinct pathways: direct allorecognition in which $\mathrm{T}$ cells recognize intact donor MHC molecules as well as the semidirect mechanism dependent on donor-derived MHC-peptide complex, which traffics via extracellular vesicles to be presented upon recipient antigen-presenting cells (APCs). In this case, the recipient dendritic cell (DC) becomes chimeric for donor allopeptide-MHC complex and can present to donor responsive $\mathrm{CD}^{+} \mathrm{T}$ cells through the direct pathway (13). It is important to note that some complex can undergo internalization, degradation, loading, and presentation on MHC-II to $\mathrm{CD}^{+} \mathrm{T}$ cells in the same manner as below in the indirect pathway. Thus, a single DC can present to both $\mathrm{CD}^{+}$and $\mathrm{CD}^{+}$cells resulting in a linked activation of T cells (14). The indirect pathway involves $\mathrm{T}$ cells, which interact with donor peptides bound to recipient MHC molecules on host APCs (15-18). This process leads to the differentiation of $\mathrm{CD}^{+}$cytotoxic $\mathrm{T}$ lymphocytes (CTL) and to plasmocytes (B cells), which produce donor-specific antibodies (DSAs) (19). B cells play a key role in acute and chronic allograft rejection through their production of DSAs, a process requiring help from $\mathrm{CD} 4^{+} \mathrm{T}$ cells activated indirectly (20). In addition, B cells serve as APCs and present alloantigen peptides to $\mathrm{T}$ cells thereby contributing to their activation and differentiation into memory $\mathrm{T}$ cells $(21,22)$. On the other hand, certain B cell subsets can suppress inflammatory alloreactive $\mathrm{T}$ cells and promote allograft tolerance (23-27). In this article, we present recent data from human and animal studies that raise exciting new possibilities for $\mathrm{B}$ cells in antigen presentation and $\mathrm{T}$ cell regulation relevant to transplantation.

\section{ALLORECOGNITION BY B CELLS}

B cells have a critical role in indirect allorecognition. The traditional immunological concepts for developing an adaptive response to any given protein antigen underpin the so-called indirect pathway of allorecognition. Recipient T cells recognize processed allopeptide-self-MHC-II complexes on recipient APCs (28-30). The indirect response is primarily CD4 ${ }^{+} \mathrm{T}$ celldriven due to the involvement of self-MHC-II molecules (31, 32). Following recognition of cognate antigen on DCs in the $\mathrm{T}$ cell zone, these CD4 ${ }^{+} \mathrm{T}$ cells upregulate BCL6, CXCR5, and CD40L and downregulate CCR7, which allows them to migrate to the follicle where they take on the follicular $\mathrm{T}$ helper cell phenotype (33). These cells can then instruct follicular B cells, which have internalized donor antigen to seed germinal centers (GCs) via the CD40L/CD40 axis as well as the secretion of IL-21 promoting the differentiation of CD40L stimulated B cells (34). These B cells undergo somatic hypermutation, a critical step to generating high-affinity DSA (35). They also class switch and some differentiate into plasma cells (with highest BCR signal strength) or memory B cells if density and tonicity of the B cell receptor signaling are insufficient to differentiate to a plasma or GC B cell (36). Thus, the presence of DSA can be used as a proxy measure of the activity of the indirect pathway $(37,38)$. In addition to alloreactive or DSA, B cells can generate antibody responses against non-HLA self-peptides, the angiotensin II receptor is an example of an activating antibody leading to a functional change following renal transplantation (39). The extent to which these antibodies contribute to rejection, especially chronic vascular type rejection is as of yet unclear; however, the mechanism of generation in the face of varying degrees of allograft tolerance (DSA levels) is intriguing (40).

\section{B CELLS AS APCs}

B cells are likely to play a role in antigen presentation associated with indirect activation of donor-specific T cells. For example, the presence of $\mathrm{CD} 20^{+}$cells in renal allografts is associated with poor outcomes and acute cellular rejection, but not necessarily antibody-mediated rejection (AMR), in renal transplantation (41). B cells present in these grafts presumably mediate their effects through alloantigen presentation and ICOS/CD28 costimulation of $\mathrm{T}$ cells leading to their activation and expansion (42). Graft infiltrating $\mathrm{CD} 20^{+} \mathrm{CD} 27^{+}$memory B cells survey for cognate antigen prior to expanding and seeding GCs, a process leading to increased DSA production and subsequent acute and chronic rejection (43). These DSAs have the potential to greatly modify the interplay of donor antigen and recipient tolerance since bound antibodies have the potential to fix complement and lead to increased tissue damage and increased antigen presentation, as well as epitope spreading, leading to tissue-specific responses as in the indirect pathway described above (44).

\section{ROLE OF B CELLS IN SUPPRESSING INFLAMMATORY ALLOIMMUNITY}

B cells may not always act as pro-inflammatory players. In human renal transplantation, B cells were recently shown to have a regulatory role on $\mathrm{T}$ cell alloresponses in vitro using peripheral blood from 65 patients with biopsy-proven AMR, non-immune related graft dysfunction, or stable graft function (45). The authors found many biopsy-proven AMR samples that did not demonstrate an anti-donor IFN-gamma response unless $\mathrm{CD}^{+} 5^{+}$(regulatory T cells) and $\mathrm{CD} 19^{+}$cells (B cells) were depleted. More importantly, depletion of these cells also restored alloresponsiveness in patients with no histological signs of immune-mediated graft dysfunction. Alloresponsiveness was dependent on $\mathrm{B}-\mathrm{T}$ interactions (with $\mathrm{CD} 19^{+}$cells acting as APCs in vitro).

A clinical trial in renal transplantation compared the efficacy of rituximab, a monoclonal anti-CD20 antibody, with daclizumab, a monoclonal anti-CD25 antibody (46) as induction therapy. This trial was halted early due to dramatically increased rates of biopsy-confirmed acute rejection (within the first 3 months post-transplant) in the rituximab-treated group compared with daclizumab ( 83 versus $14 \% ; p=0.01$ ). In fact, the rate of acute rejection observed in the rituximab-treated group exceeded previously observed rates in recipients that did not receive any induction therapy $(\sim 35 \%)$, suggesting that B cell depletion actually increased alloreactivity. Another study sought to evaluate rituximab for desensitization prior to HLA-incompatible live donor renal transplantation. Rituximab-treated recipients exhibited a trend toward higher rates of acute rejection and greater 
number of episodes of rejection compared with non-rituximab recipients (47). These studies' results are in line with animal models showing worsening of disease severity along several T-dependent autoimmune models including ulcerative colitis (48), psoriasis (49), and autoimmune encephalomyelitis/multiple sclerosis (EAE/MS) (50) following anti-CD20 mAb-mediated B cell depletion, despite decreases in circulating autoantibodies, underscoring the antibody-independent role of B cells in autoimmunity. However, other studies including rituximab in the induction period for $\mathrm{ABO}$ incompatible desensitization did not show statistically significant differences in rates of acute rejection, although they did raise the concern of possible increased risk of cardiac mortality following B cell depletion $(51,52)$.

The role of $\mathrm{B}$ cells with regulatory potential has also been explored in human hematopoietic stem cell transplantation. Chronic graft versus host disease (cGVHD) is a debilitating complication that carries a poor prognosis in patients who fail to respond to corticosteroids $(53,54)$. A frequent observation in GVHD is increased titers of autoantibody that demonstrates a loss of peripheral B cell tolerance (54). Khoder et al. examined the frequencies of regulatory B cells in GVHD and healthy controls and found that the ratio of IL- $10^{+} \mathrm{B}$ cells to IFN-gamma $\mathrm{CD} 4^{+} \mathrm{T}$ cells was greatly reduced in cGVHD patients compared to stable controls (55). They found B cells with regulatory function (Bregs) (as measured by the ability to suppress CD $4^{+}$ $\mathrm{T}$ cell proliferation and effector function in vitro) in both the IgM memory $\left(\mathrm{CD} 19^{+} \operatorname{IgM}^{+} \mathrm{CD} 27^{+}\right)$and transitional B cell $(\operatorname{TrB}$; $\mathrm{CD} 19^{+} \mathrm{CD} 24^{\mathrm{hi}} \mathrm{CD} 38^{\mathrm{hi}}$ ) compartments. They also demonstrated that the regulatory potential of these cells required cell-cell contact by coculturing both IgM memory and $\operatorname{TrB}$ cells in transwell plates with anti-CD3 and anti-CD28 antibody-activated CD4 ${ }^{+}$ $\mathrm{T}$ cells. CD80/CD86 blockade in coculture systems was also found to be deleterious to the development of full regulatory effect by Bregs, and that this effect was independent of CD80/ PD-1 interactions. The necessity for cell-cell contact combined with the ability of B cells to act as APC raises the question of whether Bregs are antigen-specific via either the $\mathrm{B}$ cell receptor or MHC, although there have been no reports of direct evidence supporting either possibility.

Future work needs to be done to clarify the ontogeny of donor-specific "regulatory" B cells [current definitions rely on functional production of IL-10 (56-58)]. The regulatory B cell populations in murine models are more fully characterized and reliably defined by phenotypic markers compared with humans. Although no fewer than 10 subsets have been defined as "Bregs," most work has been done on either marginal zone precursor B2 cells or B10 cells, which are typically $\mathrm{CD} 19^{+} \mathrm{CD} 1 \mathrm{~d}^{\text {hi }} \mathrm{CD} 5^{+}$ (a population, which overlaps with marginal zone B2 cells, marginal zone precursor B2 cells, and B1 cells) (59). However, many still perform in vitro assays using anti-CD40 antibodies, and PMA-ionomycin, followed by monensin or brefeldin treatment to stimulate IL-10-competent B cells to produce and retain this cytokine for intracellular staining (25). In humans, only a small percentage of cells identified as potentially regulatory by phenotypic markers produce IL-10, a finding that makes translation more difficult $(60,61)$.
One of the first animal models to demonstrate the regulatory role of B cells in transplantation was performed in a murine renal transplantation model where greater efficiency of tolerogenesis was observed by transplanting donor B cells at the time of renal transplantation than with donor T cells (62). Since that time, laboratory efforts have identified several subtypes of B cells with regulatory potential (63).

In a murine model of pancreatic islet allotransplantation, $\mathrm{T}$ cell Ig domain and mucin domain protein 1 (TIM-1), a costimulatory molecule was shown to modulate $\mathrm{CD} 4^{+} \mathrm{T}$ cell reactivity and serves as a marker of Bregs (27). TIM-1 broadly marked Bregs with significant overlap with IL- $10^{+}$capable cells. In fact, TIM-1 ligation actually enhanced production and secretion of IL-4 and IL-10 by B cells. Compared to other reports, this group was able to more reliably identify IL- $10^{+}$cells in peripheral tissues and secondary lymphoid organs as compared to spleen using TIM-1 positivity as opposed to a non-specific $\mathrm{CD} 19^{+} \mathrm{CD} 1 \mathrm{~d}^{\text {hi }} \mathrm{CD} 5^{+}$gate. Finally, they were able to promote tolerogenesis via RMT1-10, an anti-TIM-1 mAb, which simulates CD4 ${ }^{+}$binding. This work was furthered by identifying the role of Breg-derived TGF-beta in inducing Tregs and in promoting tolerance to fully MHCmismatched pancreatic islet transplants. Tolerance induction in these mice was transferrable through injection of naïve mice with $B$ cells from dual antibody-treated recipients (antiCD45RB and anti-TIM-1) (24). This dual therapy promoted TGF-beta secretion by TIM-1 ${ }^{+}$B cells and led to a substantial increase in Treg frequencies, which was blocked by anti-TGFbeta antibody (26).

\section{CONCLUSION}

It is clear that great strides are being made across the field of transplantation with respect to the understanding of the many roles of B cells. B cells are unique in their ability to produce antibodies, which can kill donor cells via antibody-dependent cell-mediated cytotoxicity and complement fixation. In addition, B cells are efficient APCs providing help to T cells thereby polarizing the $\mathrm{T}$ cell response and promoting the differentiation of memory T cells. However, mechanistically informed clinical trials, which sought to take advantage of the indirect pathway of allorecognition via $\mathrm{CD}_{2} 0^{+}$antibody treatment to deplete recipient $\mathrm{B}$ cells, resulted in increased rates of acute cellular rejection. This peculiar result challenges the single faceted view of B cells as solely pro-inflammatory and supports the human relevance of recent laboratory work in rodents, which has demonstrated immunoregulatory roles for several B cell subsets. Future work needs to characterize the transcriptome of Bregs in an effort to identify a transcription factor necessary for function regulation such as Foxp3 in Tregs. Critical questions remain about whether the variety of reported Bregs are indeed separate cell subsets or merely different activation states of $\mathrm{B}$ cells across development. This would help to explain such diverse findings in B10, marginal zone precursors, and TIM- $1^{+}$ $B$ cells and would open up the exploration of what cytokine environment polarizes a Breg and might be useful in clinical transplantation. 


\section{AUTHOR CONTRIBUTIONS}

All authors listed have made substantial, direct, and intellectual contribution to the work and approved it for publication.

\section{REFERENCES}

1. Lechler R, Lombardi G. Structural aspects of allorecognition. Curr Opin Immunol (1991) 3:715-21. doi:10.1016/0952-7915(91)90102-7

2. Ingulli E. Mechanism of cellular rejection in transplantation. Pediatr Nephrol (2010) 25:61-74. doi:10.1007/s00467-008-1020-x

3. Zakrzewski JL, van den Brink MRM, Hubbell JA. Overcoming immunological barriers in regenerative medicine. Nat Biotechnol (2014) 32:786-94. doi:10.1038/nbt.2960

4. Rosenberg AS, Singer A. Cellular basis of skin allograft rejection: an in vivo model of immune-mediated tissue destruction. Annu Rev Immunol (1992) 10:333-58. doi:10.1146/annurev.iy.10.040192.002001

5. Bharat A, Mohanakumar T. Allopeptides and the alloimmune response. Cell Immunol (2007) 248:31-43. doi:10.1016/j.cellimm.2007.03.010

6. Lakkis FG, Dellaporta SL, Buss LW. Allorecognition and chimerism in an invertebrate model organism. Organogenesis (2008) 4:236-40. doi:10.4161/ org.4.4.7151

7. Oberbarnscheidt $\mathrm{MH}$, Zecher D, Lakkis FG. The innate immune system in transplantation. Semin Immunol (2011) 23:264-72. doi:10.1016/j.smim. 2011.06.006

8. Zecher D, van Rooijen N, Rothstein DM, Shlomchik WD, Lakkis FG. An innate response to allogeneic nonself mediated by monocytes. J Immunol (2009) 183:7810-6. doi:10.4049/jimmunol.0902194

9. Steinmuller D. Passenger leukocytes and the immunogenicity of skin allografts. J Invest Dermatol (1980) 75:107-15. doi:10.1111/1523-1747. ep12521331

10. Barker CF, Billingham RE. The role of afferent lymphatics in the rejection of skin homografts. J Exp Med (1968) 128:197-221. doi:10.1084/jem.128.1.197

11. Larsen CP, Morris PJ, Austyn JM. Migration of dendritic leukocytes from cardiac allografts into host spleens. A novel pathway for initiation of rejection. J Exp Med (1990) 171:307-14. doi:10.1084/jem.171.1.307

12. Brown K, Fidanboylu M, Wong W. Intercellular exchange of surface molecules and its physiological relevance. Arch Immunol Ther Exp (Warsz) (2010) 58:263-72. doi:10.1007/s00005-010-0085-y

13. Smyth LA, Herrera OB, Golshayan D, Lombardi G, Lechler RI. A novel pathway of antigen presentation by dendritic and endothelial cells: implications for allorecognition and infectious diseases. Transplantation (2006) 82:S15-8. doi:10.1097/01.tp.0000231347.06149.ca

14. Benichou G, Tocco G. The road to transplant tolerance is paved with good dendritic cells: highlights. Eur J Immunol (2013) 43:584-8. doi:10.1002/ eji.201343361

15. Benichou G. Direct and indirect antigen recognition: the pathways to allograft immune rejection. Front Biosci (1999) 4:D476-80. doi:10.2741/A442

16. Leddon SA, Sant AJ. Generation of MHC class II-peptide ligands for CD4 T-cell allorecognition of MHC class II molecules. Curr Opin Organ Transplant (2010) 15:505-11. doi:10.1097/MOT.0b013e32833bfc5c

17. Felix NJ, Allen PM. Specificity of T-cell alloreactivity. Nat Rev Immunol (2007) 7:942-53. doi:10.1038/nri2200

18. Benichou G, Thomson AW. Direct versus indirect allorecognition pathways: on the right track. Am J Transplant (2009) 9:655-6. doi:10.1111/j.16006143.2009.02572.x

19. Auchincloss H, Sultan H. Antigen processing and presentation in transplantation. Curr Opin Immunol (1996) 8:681-7. doi:10.1016/S0952-7915(96) 80086-0

20. Vongwiwatana A, Tasanarong A, Hidalgo LG, Halloran PF. The role of B cells and alloantibody in the host response to human organ allografts. Immunol $\operatorname{Rev}(2003)$ 196:197-218. doi:10.1046/j.1600-065X.2003.00093.x

21. Whitmire JK, Asano MS, Kaech SM, Sarkar S, Hannum LG, Shlomchik MJ, et al. Requirement of B cells for generating CD4+ T cell memory. J Immunol (2009) 182:1868-76. doi:10.4049/jimmunol.0802501

\section{FUNDING}

DF is supported by a Howard Hughes Medical Institute Medical Research Fellowship. HY is supported by NIDDK grant 1K08DK094965-01A1.

22. Ng Y-H, Oberbarnscheidt MH, Chandramoorthy HCK, Hoffman R, Chalasani G. B cells help alloreactive $\mathrm{T}$ cells differentiate into memory T cells. Am J Transplant (2010) 10:1970-80. doi:10.1111/j.1600-6143. 2010.03223.x

23. Adams AB, Newell KA. B cells in clinical transplantation tolerance. Semin Immunol (2012) 24:92-5. doi:10.1016/j.smim.2011.08.019

24. Lee KM, Kim JI, Stott R, Soohoo J, O'Connor MR, Yeh H, et al. Anti-CD45RB/ anti-TIM-1-induced tolerance requires regulatory B cells. Am J Transplant (2012) 12:2072-8. doi:10.1111/j.1600-6143.2012.04055.x

25. Chesneau M, Michel L, Degauque N, Brouard S. Regulatory B cells and tolerance in transplantation: from animal models to human. Front Immuno (2013) 4:497. doi:10.3389/fimmu.2013.00497

26. Lee KM, Stott RT, Zhao G, SooHoo J, Xiong W, Lian MM, et al. TGF-B producing regulatory $\mathrm{B}$ cells induce regulatory $\mathrm{T}$ cells and promote transplantation tolerance. Eur J Immunol (2014) 44:1728-36. doi:10.1002/eji.201344062

27. Ding Q, Yeung M, Camirand G, Zeng Q, Akiba H, Yagita H, et al. Regulatory B cells are identified by expression of TIM-1 and can be induced through TIM-1 ligation to promote tolerance in mice. J Clin Invest (2011) 121:3645-56. doi:10.1172/JCI46274

28. Fangmann J, Dalchau R, Fabre JW. Rejection of skin allografts by indirect allorecognition of donor class I major histocompatibility complex peptides. J Exp Med (1992) 175:1521-9. doi:10.1084/jem.175.6.1521

29. Liu Z, Sun YK, Xi YP, Maffei A, Reed E, Harris P, et al. Contribution of direct and indirect recognition pathways to T cell alloreactivity. J Exp Med (1993) 177:1643-50. doi:10.1084/jem.177.6.1643

30. Benichou G, Takizawa PA, Olson CA, McMillan M, Sercarz EE. Donor major histocompatibility complex (MHC) peptides are presented by recipient MHC molecules during graft rejection. J Exp Med (1992) 175:305-8. doi:10.1084/ jem.175.1.305

31. Csencsits K, Wood S, Lu G, Magee J, Eichwald E, Chang C-H, et al. Graft rejection mediated by $\mathrm{CD} 4+\mathrm{T}$ cells via indirect recognition of alloantigen is associated with a dominant Th2 response. Eur J Immunol (2005) 35:843-51. doi:10.1002/eji.200425685

32. Plenter RJ, Grazia TJ, Doan AN, Gill RG, Pietra BA. CD4 T cells mediate cardiac xenograft rejection via host MHC Class II. J Heart Lung Transplant (2012) 31:1018-24. doi:10.1016/j.healun.2012.05.018

33. Fazilleau N, McHeyzer-Williams LJ, Rosen H, McHeyzer-Williams MG. The function of follicular helper $\mathrm{T}$ cells is regulated by the strength of $\mathrm{T}$ cell antigen receptor binding. Nat Immunol (2009) 10:375-84. doi:10.1038/ ni. 1704

34. Ma CS, Deenick EK, Batten M, Tangye SG. The origins, function, and regulation of T follicular helper cells. J Exp Med (2012) 209:1241-53. doi:10.1084/ jem.20120994

35. Victora GD, Schwickert TA, Fooksman DR, Kamphorst AO, Meyer-Hermann M, Dustin ML, et al. Germinal center dynamics revealed by multiphoton microscopy with a photoactivatable fluorescent reporter. Cell (2010) 143:592-605. doi:10.1016/j.cell.2010.10.032

36. Kurosaki T, Kometani K, Ise W. Memory B cells. Nat Rev Immunol (2015) 15:149-59. doi:10.1038/nri3802

37. Steele DJ, Laufer TM, Smiley ST, Ando Y, Grusby MJ, Glimcher LH, et al. Two levels of help for B cell alloantibody production. J Exp Med (1996) 183:699-703. doi:10.1084/jem.183.2.699

38. Haynes LD, Jankowska-Gan E, Sheka A, Keller MR, Hernandez-Fuentes MP, Lechler RI, et al. Donor-specific indirect pathway analysis reveals a B-cell-independent signature which reflects outcomes in kidney transplant recipients: indirect pathway in renal transplant patients. Am J Transplant (2012) 12:640-8. doi:10.1111/j.1600-6143.2011.03869.x

39. Dragun D, Müller DN, Bräsen JH, Fritsche L, Nieminen-Kelhä M, Dechend $\mathrm{R}$, et al. Angiotensin II type 1-receptor activating antibodies in renal-allograft rejection. N Engl J Med (2005) 352:558-69. doi:10.1056/NEJMoa035717 
40. Zhang Q, Reed EF. The importance of non-HLA antibodies in transplantation. Nat Rev Nephrol (2016) 12:484-95. doi:10.1038/nrneph.2016.88

41. Hippen BE, DeMattos A, Cook WJ, Kew CE, Gaston RS. Association of $\mathrm{CD} 20+$ infiltrates with poorer clinical outcomes in acute cellular rejection of renal allografts. Am J Transplant (2005) 5:2248-52. doi:10.1111/j.1600-6143.2005.01009.x

42. Du JF, Li Q-Y, Ji XQ, Chen G, Bai X, Zuo F-Y, et al. Inhibition of T-cell expansion caused by inducible costimulator/B7h costimulation blockade in direct allorecognition pathway. Transplant Proc (2011) 43:3960-3. doi:10.1016/j. transproceed.2011.09.044

43. Zarkhin V, Kambham N, Li L, Kwok S, Hsieh S-C, Salvatierra O, et al. Characterization of intra-graft $\mathrm{B}$ cells during renal allograft rejection. Kidney Int (2008) 74:664-73. doi:10.1038/ki.2008.249

44. Ciubotariu R, Liu Z, Colovai AI, Ho E, Itescu S, Ravalli S, et al. Persistent allopeptide reactivity and epitope spreading in chronic rejection of organ allografts. J Clin Invest (1998) 101:398-405. doi:10.1172/JCI1117

45. Shiu KY, McLaughlin L, Rebollo-Mesa I, Zhao J, Semik V, Cook HT, et al. B-lymphocytes support and regulate indirect T-cell alloreactivity in individual patients with chronic antibody-mediated rejection. Kidney Int (2015) 88:560-8. doi:10.1038/ki.2015.100

46. Clatworthy MR, Watson CJE, Plotnek G, Bardsley V, Chaudhry AN, Bradley JA, et al. B-cell-depleting induction therapy and acute cellular rejection. $N$ Engl J Med (2009) 360:2683-5. doi:10.1056/NEJMc0808481

47. Jackson AM, Kraus ES, Orandi BJ, Segev DL, Montgomery RA, Zachary AA. A closer look at rituximab induction on HLA antibody rebound following HLA-incompatible kidney transplantation. Kidney Int (2015) 87:409-16. doi:10.1038/ki.2014.261

48. Goetz M, Atreya R, Ghalibafian M, Galle PR, Neurath MF. Exacerbation of ulcerative colitis after rituximab salvage therapy. Inflamm Bowel Dis (2007) 13:1365-8. doi:10.1002/ibd.20215

49. Dass S, Vital EM, Emery P. Development of psoriasis after B cell depletion with rituximab. Arthritis Rheum (2007) 56:2715-8. doi:10.1002/art.22811

50. Matsushita T, Yanaba K, Bouaziz J-D, Fujimoto M, Tedder T. F. Regulatory $\mathrm{B}$ cells inhibit EAE initiation in mice while other B cells promote disease progression. J Clin Invest (2008) 118:3420-30. doi:10.1172/JCI36030

51. Van den Hoogen MWF, Kamburova EG, Baas MC, Steenbergen EJ, Florquin S, M. Koenen HJ, et al. Rituximab as induction therapy after renal transplantation: a randomized, double-blind, placebo-controlled study of efficacy and safety: rituximab in renal transplantation. Am J Transplant (2015) 15:407-16. doi:10.1111/ajt.13052

52. Macklin PS, Morris PJ, Knight SR. A systematic review of the use of rituximab as induction therapy in renal transplantation. Transplant Rev (2015) 29:103-8. doi:10.1016/j.trre.2014.12.001

53. Flowers MED, Martin PJ. How we treat chronic graft-versus-host disease. Blood (2015) 125:606-15. doi:10.1182/blood-2014-08-551994
54. Socie G, Ritz J. Current issues in chronic graft-versus-host disease. Blood (2014) 124:374-84. doi:10.1182/blood-2014-01-514752

55. Khoder A, Sarvaria A, Alsuliman A, Chew C, Sekine T, Cooper N, et al. Regulatory B-cells are enriched within the IgM memory and transitional subsets in healthy donors but deficient in chronic graft-versus-host disease. Blood (2014) 124:2034-45. doi:10.1182/blood-2014-04-571125

56. Yanaba K, Bouaziz J-D, Matsushita T, Magro CM, St Clair EW, Tedder TF. B-lymphocyte contributions to human autoimmune disease. Immunol Rev (2008) 223:284-99. doi:10.1111/j.1600-065X.2008.00646.x

57. Yoshizaki A, Miyagaki T, DiLillo DJ, Matsushita T, Horikawa M, Kountikov EI, et al. Regulatory B cells control T-cell autoimmunity through IL-21dependent cognate interactions. Nature (2012) 491:264-8. doi:10.1038/ nature11501

58. Mauri C, Ehrenstein MR. The 'short' history of regulatory B cells. Trends Immunol (2008) 29:34-40. doi:10.1016/j.it.2007.10.004

59. Rosser EC, Mauri C. Regulatory B cells: origin, phenotype, and function. Immunity (2015) 42:607-12. doi:10.1016/j.immuni.2015.04.005

60. Iwata Y, Matsushita T, Horikawa M, DiLillo DJ, Yanaba K, Venturi GM, et al Characterization of a rare IL-10-competent B-cell subset in humans that parallels mouse regulatory B10 cells. Blood (2011) 117:530-41. doi:10.1182/ blood-2010-07-294249

61. Blair PA, Noreña LY, Flores-Borja F, Rawlings DJ, Isenberg DA, Ehrenstein $\mathrm{MR}$, et al. CD19+CD24hiCD38hi B cells exhibit regulatory capacity in healthy individuals but are functionally impaired in systemic lupus erythematosus patients. Immunity (2010) 32:129-40. doi:10.1016/j.immuni.2009. 11.009

62. Yan Y, van der Putten K, Bowen DG, Painter DM, Kohar J, Sharland AF, et al. Postoperative administration of donor $\mathrm{B}$ cells induces rat kidney allograft acceptance: lack of association with $\mathrm{TH} 2$ cytokine expression in long-term accepted grafts1. Transplantation (2002) 73:1123-30. doi:10.1097/00007890-200204150-00020

63. Nouël A, Simon Q, Jamin C, Pers J-O, Hillion S. Regulatory B cells: an exciting target for future therapeutics in transplantation. Front Immunol (2014) 5:11. doi:10.3389/fimmu.2014.00011

Conflict of Interest Statement: The authors declare that the research was conducted in the absence of any commercial or financial relationships that could be construed as a potential conflict of interest.

Copyright (c) 2017 Firl, Benichou, Kim and Yeh. This is an open-access article distributed under the terms of the Creative Commons Attribution License (CC BY). The use, distribution or reproduction in other forums is permitted, provided the original author(s) or licensor are credited and that the original publication in this journal is cited, in accordance with accepted academic practice. No use, distribution or reproduction is permitted which does not comply with these terms. 